\title{
A STUDY ON THE GROWING POPULARITY AND PURCHASE OF FASHION PRODUCT FROM ONLINE STORES IN INDIA
}

\author{
Afrose Fathima Farid ${ }^{1}$ \\ ${ }^{1}$ Assistant Professor, Department of Post Graduate Research Studies in Home Science - Textile Science and Fashion Designing, \\ Justice Basheer Ahmed Sayeed College for Women, Chennai-600018, Tamil Nadu, India. \\ afrosef@gmail.com
}

\begin{abstract}
The onset of online shopping has changed the very dimension of clothing purchase. Online purchase over the last two decades has slowly been gaining popularity worldwide. Although it is at a nascent stage in India it has made an impact in every urban home. This study was undertaken to study the impact of Indian online fashion products purchase. 170 respondents between the age group of 18 - 60 years of both the sex, from different parts of India, with different backgrounds were surveyed. It was understood from the outcome of study that retail stores are still the preferred place for purchase. Most of the people now a day's possessed card which helped in their online transaction. Casual wear clothing below the price range of Rs. 2000 was the most preferred item for purchase. Factors such as ease of purchase, wide cost range, brand diversification along with the discount benefit motivated the Indian customers towards purchasing fashion products from online stores.
\end{abstract}

Keywords: Clothing, Cost, Fashion Products, Online Purchase, Shopping, Value

$* * *$

\section{INTRODUCTION}

Internet plays an important role in the daily lives of people throughout the world. Shopping online for clothing products is gaining popularity. ${ }^{1}$ Online shopping is defined as the process where a customer undertakes to purchase a service or product over the internet. This concept was first demonstrated before the World Wide Web (www). The technology was called as video text and was first demonstrated in 1979 by M. Aldrick who designed and installed the systems in United Kingdom. By $1990 \mathrm{~T}$. Berners-Lee created the first www server and browser and by 1995 Amazon expanded its online shopping experiences. ${ }^{2}$ E-commerce offers a lot of tangible advantages like, reduction in buyers sorting out time, better buying decision, 24 hours shopping, open all 365 days and commerce expansion beyond geographical reach of consumers who can purchase from anywhere any goods. Hence, online shopping is environment friendly compared to stores because consumers can just fulfil his desire without going out from the house. ${ }^{3}$

Though online stores are relatively new in the global apparel industry this form of purchase is gaining popularity. With more and more daily activities making their way online since 1990's, such as banking and ordering food. Online consumers are increasingly inclined to make purchases over the internet to save time and energy. ${ }^{4}$ Internet has strongly impacted the global marketing environment and internet has provided companies with the ability to expand their business reach through e-commerce. ${ }^{5}$

The internet browsing population in India is growing at a rate of $20 \%$ annually and expected to touch 237 million by 2015. Most Indian internet users are between $25-35$ age groups. $97 \%$ of them are regular users while $79 \%$ of them are daily users. ${ }^{6}$

The global apparel retail market is expected to undergo $15 \%$ expansion in the next five years. The leading segment world wise is said to be women wear at $51 \%$. Though many countries are hit by the economic recession, the apparel retail market is still recording growth. ${ }^{4}$

The fashion e-commerce sales doubled to \$559 million compared to the previous year and will potentially go up about $\$ 2.8$ billion by 2016 rivalling electronics and mobiles which have been the biggest draw online. ${ }^{7}$ The Indian apparel industry is estimated to grow at a CAGR of $15 \%$ over the next five years. Spending on apparel constitutes around $4 \%$ of household expenditure in India. ${ }^{8}$

Indian online mega store Flipkart became the country's first online retail to hit a billion dollar in sales, with spurt in fashion sales post Myntra merger. The tie up is said to have cornered $55 \%$ of the online Indian market share with regards to fashion and apparel. ${ }^{9}$ Its Big Billion Day sale in 2014 registered \$100 million sales with its extravagant discounts on cosmetic, apparel and electronics items. This frenzie benefitted their rival's Snapdeal, Ebay and Amazon too. The fashion category clocks in about $\$ 700$ million annually. Mukesh Bansal co-founder of Flipcart-Myntra India in an interview to times of India $^{7}$ stated that "Women are emerging as a strong customer base for us, having grown from contributing $20 \%$ to our overall sales two years back to now clocking $40 \%$ sales. Women are expected to contribute $50-55 \%$ sales in the next two years". ${ }^{10}$

With the growth of the online market for fashion clothing products comes the need to understand this growing trend. 
To assess the impact of this sector on the people of India and thereby to assess the future impact it will have on our lives and on the Indian economy becomes important. Many researchers worldwide have studied this growing trend, but it still lacks in the data generated. This study intends to shed light on certain aspects like taking into account the background of the people under study and thereby forming a comprehensive picture of the situation at hand.

\section{REVIEW OF LITERATURE}

Numerous studies from different parts of the world have been reported on the online shopping behaviour. The online shopping is at its nascent stage, it is expected to take away more percentage of sales from the traditional brick and mortar stores. Reports reveal that physical brick and mortal retail store still holds the fort, with more than half of the internet shoppers preferring to make their final shopping at a retail store. ${ }^{11}$ The phenomenal growth of e-tailing has now prompted traditional stores to rethink strategies. It is predicted that the e-tail market will grow to 83,900 crores by 2019. As online shopping continues to grow at the expense of the stores, the premium in the future will be on creating unique brand defining store experiences that will keep customers coming back for more. ${ }^{12}$

Today's consumers defy classification, but universally demonstrate a significant increase in their spending pattern. As they increase the share of their spending on education, leisure and lifestyle products, there is a proportional decrease in the traditional categories like grocery, clothes and shoes. The rules of marketing are changing, and changing fast. One of the industry which would be most impacted by this change is the fashion industry. The term fashion has many connotations, the fashion industry tends to be focused on those businesses involved in the design, production and sales of clothing, accessories and footwear. ${ }^{13}$

The International Wool Textile Organization (IWTO), in a global study ${ }^{14}$ has mentioned that the consumers are becoming more price conscious, individualistic and demanding (value, fashion, quality/price).

Research concerning online clothing shopping includes the factors that motivate and inhibit such shopping ${ }^{15}$, the quality and satisfaction of the clothing websites. Factors that inhibit online clothing shopping include the inability to try on clothing and concerns about credit card security, ${ }^{17,18}$ and difficulty in assessing the quality of the products ${ }^{19}$. Factors that motivate online clothing shopping include the convenience, fun, and quickness of buying online.$^{20}$ Those who have previous internet shopping experience, those who are familiar with the brands 21 , and who search for information online ${ }^{22,23}$ were more likely to make clothing purchases online. ${ }^{24}$

Factors affecting clothing purchases are style, quality, brand and the availability of wide range of brand and clothes diversity which were found to be positively related to online purchase by Sondhi and Singhvi, (2006). ${ }^{13}$

Price has been reported to be a crucial purchase deciding factor for clothing. Moreover online shoppers are likely to perceive that prices of products in online shops are often lower than brick and mortar stores. ${ }^{25}$ Discounts are said to have an effect on clothing purchased through e commerce. The early online shoppers from India were influenced by features such as price, brand, quality and website unlike their USA early online shopper counterparts who were more influenced to shop due to price and discounts according to Gehrt et. al. (2012). ${ }^{26}$

Workman and Cho (2012) ${ }^{27}$ reported that men and women differ in fashion conscious shopping but, they do not differ in the impulsive, quality, brand or price aspects related to online shopping. Openness to online shopping was noticed among students with more positive attributes by $\mathrm{Xu}$ and Paulins (2005). ${ }^{28}$ Khare and Rakesh (2011) studied the online shopping behaviour of both male and female Indian students and conclude that male students were more positive and open towards online shopping.

Respondents frequently buy casual clothes on internet according to Napompech, (2014). ${ }^{29}$ Zuroni Md. et.al studying the factors influencing consumers attitudes towards ecommerce purchases through online shopping states that ladies clothing and accessories where preferred by $38 \%$ of the respondents. $41 \%$ of people respond to impulse buying while the rest did not. Similarly ladies clothing and accessories were more likely to be bought due to opportunistic buying. Wolfinbarger and Gilly ${ }^{30}$ concluded that $90 \%$ of the online shoppers prefer online apparel shopping to avoid shopping interference or unwanted pressure from sales assistants or spouse or children.

Goldsmith and Fynn (2004) ${ }^{31}$ found that adventurous buyer and regular catalogue buyers were more inclined towards online apparel purchase. Brand familiarity and previous experience with online shopping was found to be an important factor for clothing purchase done online ${ }^{21}$. According to Cowart and Goldsmith (2007) ${ }^{32}$ quality, brand, fashion, hedonistic shopping, impulsiveness and brand loyalty influenced online shopping behaviour pattern.

Kim $(2004)^{1}$ states that the perceived attributes of online shopping consisted of four factors: transaction/ cost, incentive, site design and interactivity influenced shopping behaviour greatly. Existing studies point out that there are several factors influencing the online purchase intention like trust, risk, internet experience, shopping orientation, online shopping experience, shopping motivation, cultural values and social influence. Each or a combination of these factors uniquely contribute to online purchase intentions. ${ }^{33}$

According to Sarkar $(2011)^{34}$, a successful online marketing must focus on increasing the hedonic value of the sites and offer stricter security to the individuals using their card for payment. ${ }^{20}$ Customer purchase intentions increased with web design, reliability/ security, responsiveness and overall service quality of the online portals. ${ }^{35}$ Shoppers feel greater risk for buying apparel products online due to inability to fully examine the product online and the substantial variation in the characteristics of apparel delivered. ${ }^{36}$

Convenience and speed of ordering affect online purchase. Delivery time delay should be compensated with free gifts 
and further discount. Since pictures sell online products, realistic pictures from different angles must be provided suggested Khare and Rakesh. Agarwal (2014) ${ }^{37}$ reports that there is a dire need to replicate the conventional shopping experience onto online shopping experience in order to attract potential Indian online shoppers.

From the above it can be understood that online shopping behaviour is a preferred study by researchers and market analyst. In spite of all this there is a paucity of research data on the Indian online apparel and fashion product customer's background and need which fuels this hedonic shopping experience.

\section{MATERIALS AND METHODS}

This study is based on empirical research conducted with the aid of a structured questionnaire. The questionnaire was administered online to elicited response from Indians from different parts of India, irrespective of caste, gender, age, belief, educational background and income. Electronic mode of survey questionnaire distribution and response collection using email, facebook messenger and facebook was employed to establish the familiarity of the respondents with internet usage and handling.

The questionnaire was constructed using survey monkey, it consisted of 23 questions aimed at understand the background of the respondents and their online purchase behaviour. 170 respondents undertook the online survey over the period of a month. The 170 surveys which were received back were complete, with no missing answers.

\section{RESULTS AND DISCUSSION}

The background details of the samples are tabulated in Table I, which clearly shows a heterogeneous mix of samples. All the 170 respondents were Indians residing in different parts of India. Majority ( $84.12 \%)$ of the respondents belonged to the age group between 18 to 35 year. Studies ${ }^{5}$ have shown that this age group is more internet friendly and that could have been the reason why they responded in a larger number to this internet survey.

Table 1 - Background Details Of The Survey Respondents

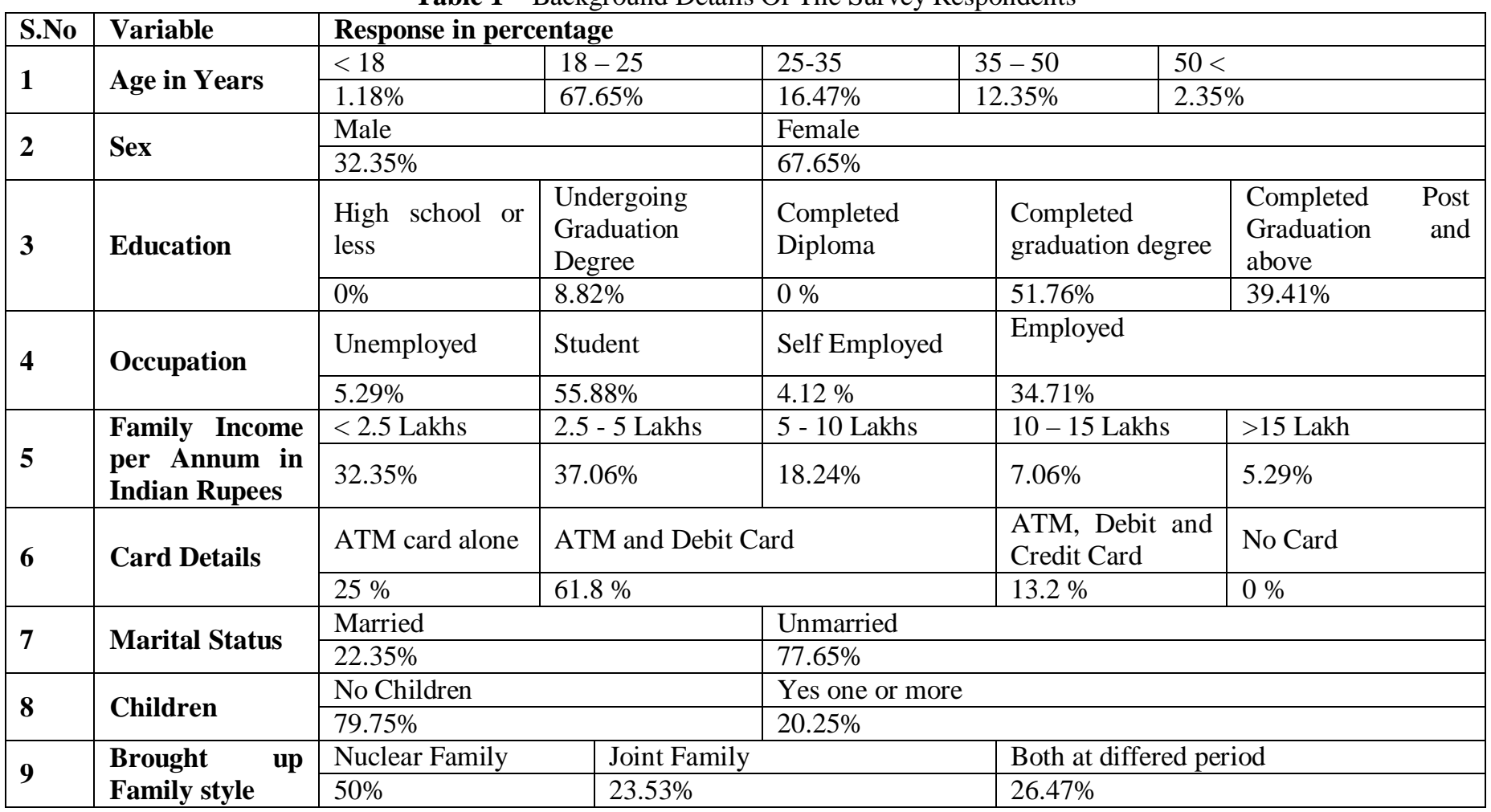

Majority of the respondents were female $68 \%$. Most of the survey respondents $(55.88 \%)$ were students doing either their graduation or post graduation course. $35 \%$ of the respondents were employed and it can be inferred from the data that they were either graduates or post graduates.

About $88 \%$ of the people who took the survey were from families earning less than 10 lakhs rupees annually. All the respondents irrespective of their sex, age, income or education was in possession of either an ATM or Debit or credit card may be due to the easy card issuing policies of the financial institutions. $75 \%$ of the sample possessed either a debit or credit card which enabled them to conduct online purchase. $77.65 \%$ of the respondents were single and hence only $20.25 \%$ had children. Majority of the respondents $(50 \%)$ were brought up in a nuclear style of family from childhood while, $26.47 \%$ who were initially brought up in a joint family now live as a nuclear family reflecting, the growing popularity of this style of family in India.

The clothing purchase pattern of the respondents has been graphically represented in Figure I. The regular clothing purchase pattern of the respondents when compared with the online purchase pattern shows that online purchase has 
induced the respondents into buying more clothes than they traditionally did. Further the percentage of online clothing purchased every month is more probably due to increased purchase after payday due to the easy access of internet and card. Out of the 170 respondents only $9.4 \%$ had never purchased clothing online while, everyone attested to having purchased atleast one fashion product in the last year from the traditional brick and mortar retail store.

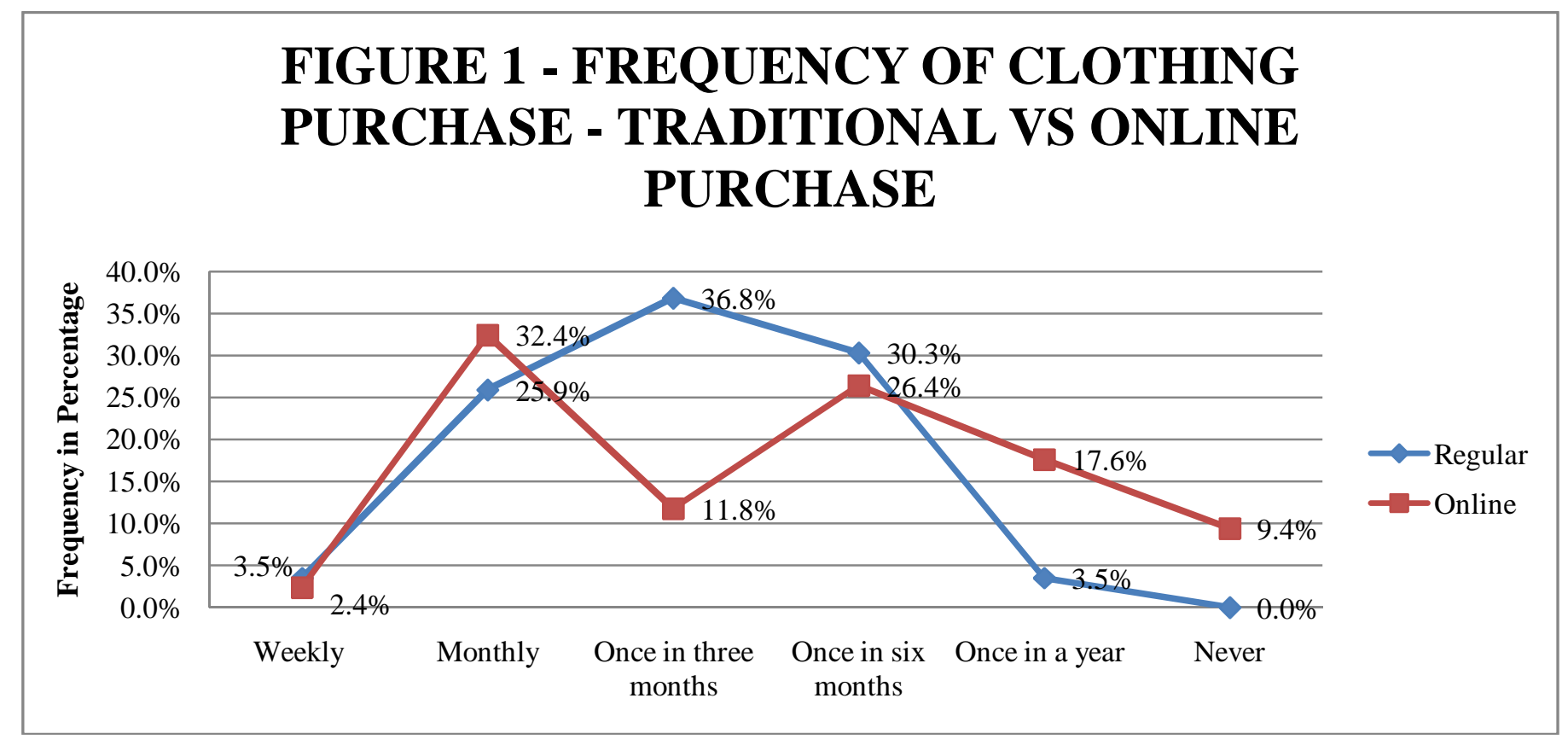

When asked about the preferred source of clothing purchase $87.06 \%$ preferred retail shops, $42.94 \%$ branded shops \& boutiques and $12.35 \%$ wholesale shops. Only $35.29 \%$ of the respondents preferred online mode of purchase. Exhibition was least preferred (8.24\%).

The response to ranking the feature which attracted the samples towards making an online purchase with regards to clothing items is given in Figure 2. It can be observed that the ease of internet access, anytime from anywhere had a maximum score of 6.66. Factor like saves time and energy ranked second with a score of 5.59. While wide cost range and good product range and brands scored 5.39, 5.32 respectively and was ranked third and fourth. Discount ranked fifth with a score of 4.52. This is consistent with other study findings. Interesting offers, product reliability and delivery policies scored 3.39, 2.63 and 2.43 respectively.

Figure 2 -Features Which Attracted Online Clothing Purchase

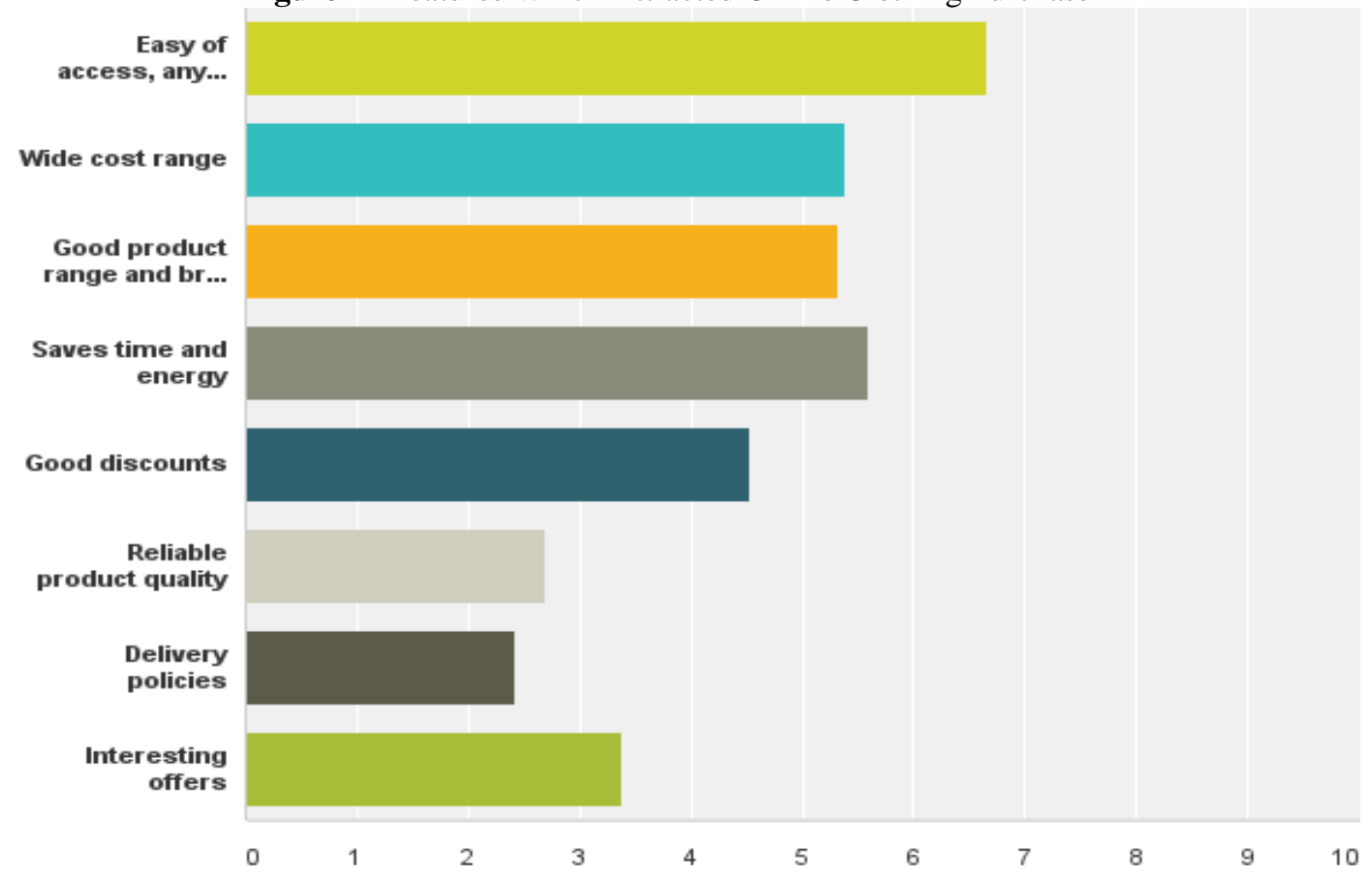


The most preferred clothing item to be purchased online was casual wear with $62.94 \%$ which is consistent with the findings of Napompech (2014) irrespective of sex, age or income. Purchase of fashion accessories, branded items and western wear were also popular but not as much as casual wear.

Among the variables which influence the final selection of a clothing product, respondents were more induced by quality of the product (5.56) while finally deciding to purchase. Colour and design was ranked second with a score of 4.88 . Brand name, fashion trend and personal style followed with scores $3.95,3.85$ and 3.66 respectively. Cost was ranked the least with a score of 3.42 .

Table II gives the ratings of the respondents when questioned about the reason for purchasing, their purchase range, server preferred for purchase, satisfaction level of the product upon usage of the online fashion products and the disadvantages of online purchase based on their experience.
From the table it can be clearly seen that important occasions, parties and festivals instigated the respondents to make online purchase with regards to fashion products more than the other variables. Discount sale and special offers emerged as the second reason for purchasing. While just like that shopping for no specific reason emerged as the third ranking. While, out of necessity was ranked only fourth. This clearly shows that the people nowadays purchase fashion products due to their increased spending power and psychological satisfaction more than actual need and necessity.

Almost $90 \%$ of the respondents who undertook this survey preferred to spend less than 2000 rs. on a single clothing product and that they never spent above 10,000 Rs. on a single online purchase. With regards to the satisfaction level of the clothes purchased upon usage $82.4 \%$ of them were satisfied since, they felt that the product was worth the money spent on it.

Table 2 - Reasons, Range, Satisfaction, Server, And Disadvantages Of Online Clothing Purchase

\begin{tabular}{|c|c|c|c|c|c|c|c|}
\hline \multirow[t]{2}{*}{$\begin{array}{l}\text { Reason for } \\
\text { Purchase }\end{array}$} & Variables & $\begin{array}{l}\text { Important } \\
\text { Occasions, } \\
\text { Parties and } \\
\text { Festivals }\end{array}$ & $\begin{array}{l}\text { Discount } \\
\text { Sale and } \\
\text { Offers } \\
\text { period }\end{array}$ & Just like that & $\begin{array}{ll}\text { Out } & \text { of } \\
\text { necessity }\end{array}$ & \multicolumn{2}{|c|}{$\begin{array}{l}\text { Social Events } \\
\text { and Meetings }\end{array}$} \\
\hline & $\begin{array}{l}\text { Response in } \\
\text { percentage } \%\end{array}$ & $29.9 \%$ & $26.82 \%$ & $23.37 \%$ & $11.13 \%$ & \multicolumn{2}{|l|}{$8.78 \%$} \\
\hline \multirow{2}{*}{$\begin{array}{l}\text { Range of } \\
\text { Purchase }\end{array}$} & $\begin{array}{l}\text { Range } \\
\text { purchased in } \\
\text { Rs. }\end{array}$ & $\begin{array}{l}\text { < Rs. } 1000 \text { per } \\
\text { item }\end{array}$ & $\begin{array}{l}1000 \quad- \\
2000 \mathrm{Rs} . \\
\text { per item }\end{array}$ & $\begin{array}{l}2000-5000 \\
\text { Rs. per item }\end{array}$ & $\begin{array}{l}5000-10000 \\
\text { Rs. per item }\end{array}$ & \multicolumn{2}{|c|}{$\begin{array}{l}\text { > Rs. } 10000 \text { Rs. } \\
\text { per item }\end{array}$} \\
\hline & $\begin{array}{l}\text { Response in } \\
\text { percentage } \%\end{array}$ & $49.4 \%$ & $40.0 \%$ & $9.4 \%$ & $1.2 \%$ & \multicolumn{2}{|l|}{$0.0 \%$} \\
\hline \multirow{2}{*}{$\begin{array}{l}\text { Product } \\
\text { Satisfaction }\end{array}$} & $\begin{array}{l}\text { Level of } \\
\text { satisfaction }\end{array}$ & \multicolumn{2}{|c|}{ Worth for the money spent } & Very Satisfied & $\begin{array}{l}\text { Not worth the } \\
\text { money spent }\end{array}$ & \multicolumn{2}{|c|}{ Dissatisfied } \\
\hline & $\begin{array}{l}\text { Response in } \\
\text { percentage } \%\end{array}$ & \multicolumn{2}{|l|}{$82.4 \%$} & $12.9 \%$ & $4.7 \%$ & \multicolumn{2}{|l|}{$0.0 \%$} \\
\hline \multirow{2}{*}{$\begin{array}{l}\text { Online } \\
\text { Server } \\
\text { Preference }\end{array}$} & $\begin{array}{l}\text { Name of Online } \\
\text { Server }\end{array}$ & Flipcart & Myntra & Amazon & Snapdeal & $\begin{array}{l}\text { Other } \\
\mathrm{s}\end{array}$ & ebay \\
\hline & $\begin{array}{l}\text { Response in } \\
\text { percentage } \%\end{array}$ & $32.72 \%$ & $23.56 \%$ & $15.91 \%$ & $14.35 \%$ & $\begin{array}{l}8.56 \\
\% \\
\end{array}$ & $4.9 \%$ \\
\hline \multirow[t]{2}{*}{$\begin{array}{l}\text { Disadvanta } \\
\text { ge of online } \\
\text { purchase }\end{array}$} & Variables & \multicolumn{2}{|c|}{ Fit trial not possible } & $\begin{array}{l}\text { Colours and } \\
\text { designs don't } \\
\text { often look the } \\
\text { same once } \\
\text { delivered }\end{array}$ & $\begin{array}{l}\text { Dis } \\
\text { satisfactory } \\
\text { pay back or } \\
\text { return } \\
\text { policies } \\
\end{array}$ & $\begin{array}{l}\text { Poor } \\
\text { Qualit } \\
\text { y }\end{array}$ & $\begin{array}{l}\text { Poor } \\
\text { Deliver } \\
\mathrm{y}\end{array}$ \\
\hline & $\begin{array}{l}\text { Response in } \\
\text { percentage } \%\end{array}$ & \multicolumn{2}{|l|}{$41.38 \%$} & $28.5 \%$ & $13.56 \%$ & $\begin{array}{l}11.6 \\
\% \\
\end{array}$ & $4.96 \%$ \\
\hline
\end{tabular}

Flipkart followed by Myntra were the most preferred server for online fashion product purchase according to majority $(56 \%)$ of the respondents. These two portals run by the same people rocketed into popularity displacing Amazon, Snapdeal and Ebay with their new discount and publicity strategy namely the 'Big Billion Day Sale' and this data could be due to the after effect of popular 'Big Billion Day Sales' soon after which this survey was conducted.

When questioned about the disadvantages of online shopping customers felt that lack of fit trail was the major hindrance towards purchasing a fashion clothing product online. While based on their previous experience colours and designs post-delivery looking different from the web picture was the second source of contention among many respondents. Poor pay back \& return policies and the uncertainty about the product quality also was voiced as a serious disadvantage with regards to online purchase.

\section{CONCLUSION}

The popularity of online shopping is growing especially with regards to fashion products but the traditional retail stores are still popular and highly sought-after. All the respondents had card at their disposal which helped in their online transaction. The availability of card with everyone now-a-days could be one of the major factors influencing the growing popularity of online purchase. Most of them purchased online due to the ease of purchase, wide cost 
range, brand diversification coupled with the discount benefits. Special occasion and discounts warranted and instigated purchase of fashion product. Casual wear purchase below the price range of Rs. 2000 was the preferred purchase item since, it does not need perfect fitting. The major drawback of e-purchase according to the respondents was said to be the lack of fit trail and the variations in the colour and look of the product upon delivery.

\section{REFRENCES}

[1]. Kim E.Y. and Kim Y.K., (2004), 'Predicting online purchase intentions for clothing products', European Journal of Marketing, Vol. 38, Iss. 7, pp. 883 -897.

[2]. Parker-Hall J., (2009), 'The History of Online Shopping', http://ezineartides.com/?the-history-ofonline-shopping\&id=2592183

[3]. Ling Z. Md. J. G. H. (2012), 'Factors influencing consumers attitudes towards e-commerce purchase through online shopping', International Journal of Humanities and Social Science, Vol. 2, No.4, February, p. 223.

[4]. (2015), 'Clothing stores industrial market research and statistics', www.nrf.com

[5]. Kailani M and Kumar R., (2011), 'Investigating uncertainty, avoidance and perceived risk for impacting internet buying : A study in three national cultures', International Journal of Business and Management, Vol. 6, No.5, pp. 76 - 92.

[6]. Arpita K. and Sapna R., (2011), Antecedents of online shopping behavior in India - An Examination, Journal of Internet Commerce, 10:4, p. 227 - 244.

[7]. Sharma S. and Kuriah B., (2014), 'Indian women will fuel \$3 billion e-shopping', Times of India, Mumbai/Bangalore, TNN, March 27.

[8]. Sahni H., 'The future of fashion apparels in India'

[9]. Sharma S., (2014), 'Flipkart sales run rate hits \$5 billion', Times of India, TNN, October 7.

[10]. (2014), The Hindu, Business-Industry, New Delhi,October 6.

[11]. Carlock B., (2015), 'People surge in online, retail physical stores rule in US', Apparel Online, March 115, pp.16-17.

[12]. SubbuR.,(2015), 'E-tailing successforces traditional retailers to rethink strategy', The Hindu, Chennai, February 24.

[13]. Sondhi N. and Singhvi S.R., (2006), 'Gender influences in garment purchase: an empirical analysis', Global Business Review, 7:1 Sage Publications New Delhi/Thousand Oaks/London, pp. 57 - 75.

[14]. International Wool Textile Organization (IWTO), 2004, 'Vision and perspective of consumer behavior \& trends in clothing', Images, 120, 35.

[15]. Goldsmith R. E. and Goldsmith E. B., (2002), 'Buying apparel over the Internet', Journal of Product and Brand Management, 11, pp. 89-102.

[16]. Kim S. and Stoel L., (2004), 'Apparel retailers: Website quality dimensions and satisfaction', Journal of Retailing and Consumer Services, 11, pp. 109-117.

[17]. Kwon K.-N., and Lee J., (2003), 'Concerns about payment security of Internet purchasers: A perspective on current on-line shoppers', Clothing and Textiles Research Journal, 21, pp. 174-184.

[18]. Xu Y. and Paulins V. A., (2005), 'College students' attitudes toward shopping online for apparel products: Exploring a rural versus urban campus', Journal of Fashion Marketing and Management, 9, pp. 420-433.

[19]. Lu Y. and Rucker M., (2006), Apparel acquisition via single vs. multiple channels: College students' perspectives in the US and China', Journal of Retailing and Consumer Services, 13, pp. 35-50.

[20]. Yoh E., Damhorst M., Sapp S., and Lazniak R., (2003), 'Consumer adoption of the Internet: The case of apparel shopping', Psychology and Marketing, 20, pp. 1095-1118.

[21]. Park J. and Stoel L., (2005), 'Effect of brand familiarity, experience and information on online apparel purchase', International Journal of Retail and Distribution Management, 33, pp. 148-160.

[22]. Kim M. A. J. and Park J., (2005), 'A consumer shopping channel extension model: Attitude shift toward the online store', Journal of Fashion Marketing and Management, 9, pp. 106-121.

[23]. Watchravesringkan K. and Shim S., (2003), 'Information search and shopping intentions through the Internet for apparel products', Clothing and Textiles Research Journal, 21, pp. 1-6.

[24]. Lennon S.J., Ha Y., Johnson K. K. P., Jasper C. R., Damhorst M.L., and Lyons N., (2009), 'Rural consumers' online shopping for food and fiber products as a form of out shopping', Clothing \& Textiles Research Journal, Volume 27 Number 1, January pp. 3-30.

[25]. Kim Y., Kim E. Y., and Kumar S., (2003), 'Testing the behavioral intentions model of online shopping for clothing', Clothing and Textiles Research Journal, 21, pp. $32-40$.

[26]. Gehrt et. al., (2012), 'Emergence of online shopping in India: Shopping orientation segments', International Journal of Retail and distribution management, Vol. 40, Iss. 10, pp. $742-758$.

[27]. Workman J.E. and Cho S., (2012), 'Gender, Fashion Consumer group, shopping orientation', Family and Consumer Science Research Journal, Vol. 40, Iss. 3, pp. $267-283$.

[28]. Xu Y. and Paulins V.A., (2005), 'College students attitude towards shopping online for apparel production : Exploring a rural versus Urban campus', Journal of Fashion Marketing and Management : An International Journal, Vol. 9, Iss.4, pp.420 - 433.

[29]. Napompech K., (2014), 'Factors driving customers to purchase clothes through e-commerce in social network', Journal of Applied Science, Issn. 1812-5654.

[30]. Wolfinbarger M. and Gilly M., 'Shopping online for freedom, control and fun'.

[31]. Ronald E., Smith G. and Flynn L.R., (2004), "Psychological and behavioral drives of online clothing purchase', Journal of Fashion Marketing and Management ; An International Journal, Vol. 8, Iss. 1, pp.84-95.

[32]. Coward K.O. and Goldsmith R.E., (2007), 'the Influence of consumer decision- making style on online apparel consumption by college students', 
International Journal of Consumer studies, Vol. 31., Iss. 6, pp. $639-647$.

[33]. Qudah O. Md. A. Al., (2013), 'A review of cultural values impact on consumers intension in the context of online shopping', Research Journal of Applied Science, Engg and Technology.

[34]. Sarkar A., (2011), 'Impact of utilitarian and hedonic shopping values on individuals, perceived benefits and risks in online shopping', International Management Review, Vol.7, No.1, pp.55.

[35]. Lee G.G. and Lin H.F., (2005), 'Customers perception of e-service quality in online shopping', International Journal of retail and Distribution Management, Vol. 33, Iss. 2, pp. $161-176$.

[36]. Dai B., (2014), 'The impact of online shopping experience on risk perceptions and online purchase intentions; Does product category matter?', Journal of Electronic Commerce Research, vol. 15, No.1, pp.13.

[37]. Agarwal R., (2013), Bridging the gap between traditional and online shopping methods for Indian Customers through digital intercultural experience', Advance in computing, communications and informatics, pp.1184-1189. 